\title{
Jökulhlaups in the Kunmalike River, southern Tien Shan mountains, Ghina
}

\author{
LIU JiNSHI \\ Lanzhou Institute of Glaciology and Geocryology, Academia Sinica, Lanzhou 730000, China
}

\begin{abstract}
Hydrological records of Kunmalike River in the southern Tien Shan show that jökulhlaups have occurred about once a year since 1956 from the glacier-dammed Lake Mertsbacher. The maximum peak discharge of the jökulhlaups is $1920 \mathrm{~m}^{3} \mathrm{~s}^{-1}$ and the maximum total volume is $3.275 \times 10^{8} \mathrm{~m}^{3}$. The release mechanism of the glacier-dammed lake is not a mechanical failure of the glacier dam, but drainage of pressurized water through a subglacial tunnel which is enlarged due to melting by frictional heat in the flowing water and advective heat from the lake. There is no relationship between the size of the jökulhlaups and the mean summer air temperature. The seasonal flood peaks in Kunmalike River have become larger and the flood periods have been prolonged both in spring and winter because of the draining of the lake. Once a jökulhlaup has started, its discharge is forecast hour by hour by extrapolating the measured hydrograph as exponential curves.
\end{abstract}

\section{INTRODUGTION}

Kunmalike River is located at the head of the Tarim River on the southern side of the Tien Shan mountains on the border between China and the Soviet Union. Its annual runoff volume is $4.54 \times 10^{9} \mathrm{~m}^{3}$ measured at the stream gauge Xiehela in China. The basin area is $12816 \mathrm{~km}^{2}$. Figure 1 shows the location of the river basin. Hydrological records indicate that jökulhlaups occur frequently in the river. The source of these

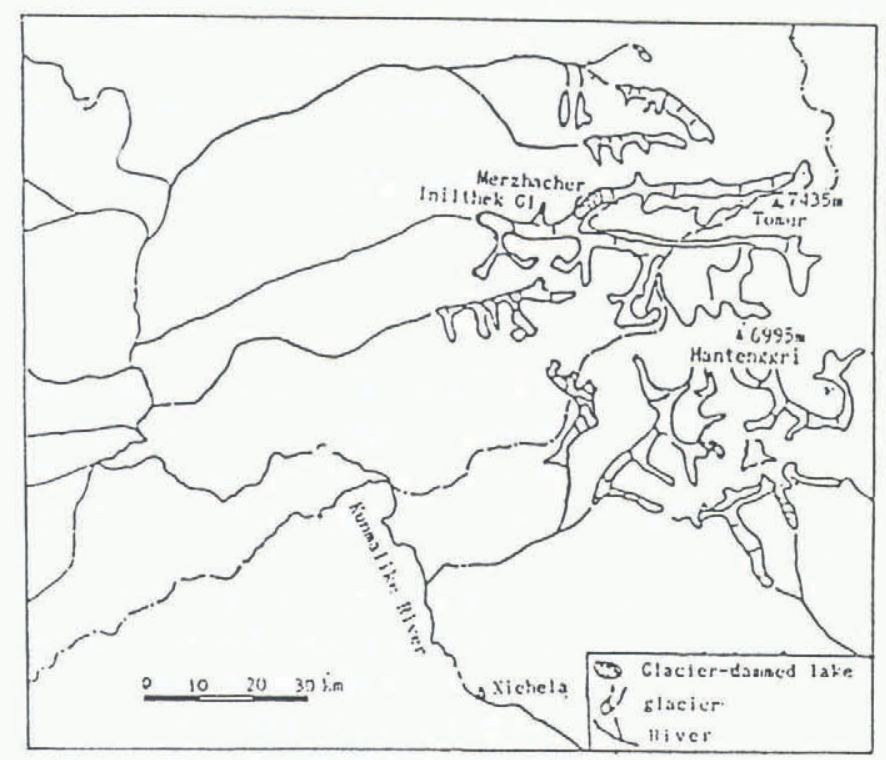

Fig. 1. The location map of Kunmalike River and the glacier-dammed Lake Mertsbacher. jökulhlaups is Lake Mertsbakher (Ozero Mertsbakhera), which is dammed by the South Iniltchek Glacier, a $65 \mathrm{~km}$ long glacier on the southern side of the Tien Shan mountains in the Soviet Union. Many glaciologists and hydrologists, most of them Russian, have investigated this glacier-dammed lake since it was discovered by G. Mertsbacher in 1902.

The volume of meltwater stored in the lake at the beginning of the jökulhlaups has ranged from $38.4 \times 10^{6} \mathrm{~m}^{3}$ to $327.4 \times 10^{6} \mathrm{~m}^{3}$. The lake drains under the glacier for a distance of $14 \mathrm{~km}$ to the glacier terminus. From this point, the water flows into the Kunmalike River and thence to the stream gauge at Xiehela, a total distance of $203 \mathrm{~km}$, where, since 1956, the Xingjiang Hydrological Service has recorded the jökulhlaups. The measured flood waves at this gauge are similar to the hydrographs measured near the glacier terminus in the Soviet Union.

The present paper describes the characteristics of the jökulhlaups from Lake Mertsbacher and discusses the twin problems of forecasting their discharges at the stream gauge and their volumes.

\section{GHARAGTERISTICS OF THE JÖKULHLAUPS AND THEIR INFLUENCE}

Table 1 lists some characteristics of the jökulhlaups recorded at Xiehela and Figure 2 shows three hydrographs in different seasons.

In general, the duration of the jökulhlaups is about one week, but the longest one was 18 days. They rise gradually to their peak and then drop abruptly in less 
Liu Jinshi: Jökulhlaups in the Kunmalike River

Table 1. Characteristics of jökulhlaups at Xiehela stream gauge in Kunmalike River

\begin{tabular}{|c|c|c|c|c|c|c|c|}
\hline Date of peak & $\begin{array}{l}Q_{\mathrm{m}} \text { peak } \\
\text { discharge }\end{array}$ & $\begin{array}{c}\text { Flood } \\
\text { duration }\end{array}$ & $\begin{array}{c}\text { Ascending } \\
\text { phase }\end{array}$ & $\begin{array}{c}\text { Descending } \\
\text { phase }\end{array}$ & $\begin{array}{c}\text { Estimated } \\
\text { volume }\end{array}$ & $\begin{array}{c}Q_{0} \\
\text { baseflow }\end{array}$ & $\begin{array}{l}\text { Ratio } \\
\ell_{\mathrm{m}} / Q_{0}\end{array}$ \\
\hline & $\mathrm{m}^{3} \mathrm{~s}^{-1}$ & $\mathrm{~d}$ & $\mathrm{~d}$ & $\mathrm{~d}$ & $10^{8} \mathrm{~m}^{3}$ & $\mathrm{~m}^{3} \mathrm{~s}^{-1}$ & \\
\hline 2 July '56 & 1740 & 5.0 & 3.8 & 1.2 & 1.164 & 626.0 & 2.8 \\
\hline 3 September ' 56 & 1900 & 8.0 & 6.5 & 1.5 & 2.954 & 280.0 & 6.8 \\
\hline 7 September '57 & 1210 & 8.0 & 6.8 & 1.2 & 1.308 & 222.0 & 5.4 \\
\hline 24 November '58 & 448 & 18.0 & 15.0 & 3.0 & 1.895 & 51.2 & 8.7 \\
\hline 19 September '59 & 1120 & 6.0 & 4.5 & 1.5 & 1.651 & 80.0 & 14.0 \\
\hline 16 July '61 & 1230 & 4.0 & 3.2 & 0.8 & 1.056 & 314.0 & 3.9 \\
\hline 6 June '63 & 925 & 11.0 & 9.0 & 2.0 & 2.931 & 190.0 & 4.9 \\
\hline 18 September '63 & 629 & 6.0 & 4.5 & 1.5 & 1.073 & 130.0 & 4.8 \\
\hline 28 September '64 & 625 & 8.0 & 6.7 & 1.3 & 0.945 & 153.0 & 4.1 \\
\hline 1 September '65 & 1090 & 7.0 & 5.5 & 1.5 & 1.416 & 230.0 & 4.7 \\
\hline 13 August '66 & 1100 & 6.0 & 5.0 & 1.0 & 1.113 & 440.0 & 2.5 \\
\hline 13 December '66 & 132 & 14.0 & 11.0 & 3.0 & 0.536 & 36.8 & 3.6 \\
\hline 13 September '67 & 920 & 9.0 & 6.0 & 2.0 & 1.920 & 214.0 & 4.3 \\
\hline 21 August '68 & 1510 & 5.0 & 3.4 & 1.6 & 1.672 & 580.0 & 4.3 \\
\hline 20 August '69 & 1540 & 7.0 & 6.2 & 0.8 & 2.254 & 340.0 & 4.5 \\
\hline 31 July '70 & 1180 & 6.0 & 5.4 & 0.6 & 1.136 & 540.0 & 2.2 \\
\hline 17 August '71 & 1080 & 7.0 & 5.8 & 1.2 & 1.551 & 408.0 & 2.6 \\
\hline 4 October '72 & 703 & 12.0 & 10.0 & 2.0 & 1.602 & 63.0 & 11.0 \\
\hline 2 September '73 & 1200 & 10.0 & 8.0 & 2.0 & 2.274 & 220.0 & 5.4 \\
\hline 8 August '74 & 1300 & 9.0 & 7.2 & 1.8 & 0.978 & 400.0 & 3.2 \\
\hline 12 September '75 & 403 & 6.0 & 5.3 & 0.7 & 0.384 & 200.0 & 2.0 \\
\hline 24 August '76 & 1110 & 7.0 & 5.5 & 1.5 & 1.663 & 268.0 & 4.1 \\
\hline 24 May '78 & 1210 & 10.0 & 8.0 & 2.0 & 3.081 & 160.0 & 7.6 \\
\hline 8 August '78 & 1490 & 4.0 & 3.4 & 1.6 & 0.502 & 1020.0 & 1.5 \\
\hline 27 May '80 & 1220 & 9.0 & 7.5 & 1.5 & 3.274 & 210.0 & 5.8 \\
\hline 12 September '80 & 1020 & 8.0 & 6.0 & 2.0 & 1.511 & 160.0 & 6.4 \\
\hline 15 July '81 & 1490 & 5.0 & 3.5 & 1.5 & 0.939 & 700.0 & 2.1 \\
\hline 21 August '82 & 1400 & 6.0 & 5.3 & 0.7 & 1.609 & 310.0 & 4.5 \\
\hline 22 August '83 & 1890 & 6.0 & 5.0 & 1.0 & 1.756 & 780.0 & 2.4 \\
\hline 26 August '84 & 1920 & 5.0 & 4.5 & 0.5 & 1.396 & 650.0 & 2.9 \\
\hline 15 August '85 & 1140 & 7.0 & 6.0 & 1.0 & 1.911 & 430.0 & 2.6 \\
\hline 1 August '86 & 1680 & 7.0 & 5.4 & 1.6 & 2.721 & 690.0 & 2.4 \\
\hline 19 August '87 & 1720 & 8.0 & 6.6 & 1.4 & 2.249 & 780.0 & 2.2 \\
\hline 12 December '88 & 583 & 13.0 & 11.0 & 2.0 & 2.071 & 41.0 & 14.0 \\
\hline
\end{tabular}

*Inferred from The Hydrology Yearbook published by Xingjiang Hydrological Service. Other figures are calculated by the author.

than one day, and occasionally in less than 10 hours. The peak discharge of the largest jökulhlaup was 1.6 times larger than that of the maximum melt flood. The volume of water drained averages $1.64 \times 10^{8} \mathrm{~m}^{3}$ for each jökulhlaup, which is $3.8 \%$ of the annual runoff at the Xiehela gauge. The maximum volume of a jökulhlaup was $3.275 \times 10^{8} \mathrm{~m}^{3}$, which is $7.2 \%$ of the annual runoff, and corresponds to the average total runoff for four months, from January to April. No systematic pattern can be found in the timing of the jökulhlaups although more than $80 \%$ of them occurred between July and September.

The probability of a jökulhlaup occurring every year is over $90 \%$, and in 1956, 1963, 1966, 1978 and 1980 two occurred. The shortest interval between jökulhlaups was only 60 days. There are no relationships between the peak discharge, volume of the jökulhlaup, and mean summer temperature.

The occurrence of jökulhlaups has an important impact on the seasonal floods and runoff in Kunmalike River. In some years the ice-dammed lake stores meltwater during the summer and drains it in jökulhlaups later during the autumn or winter. More often, however, the jökulhlaups add to the normal melt floods in summer. Thus, 12 flood peaks have exceeded $1280 \mathrm{~m}^{3} \mathrm{~s}^{-1}$, 


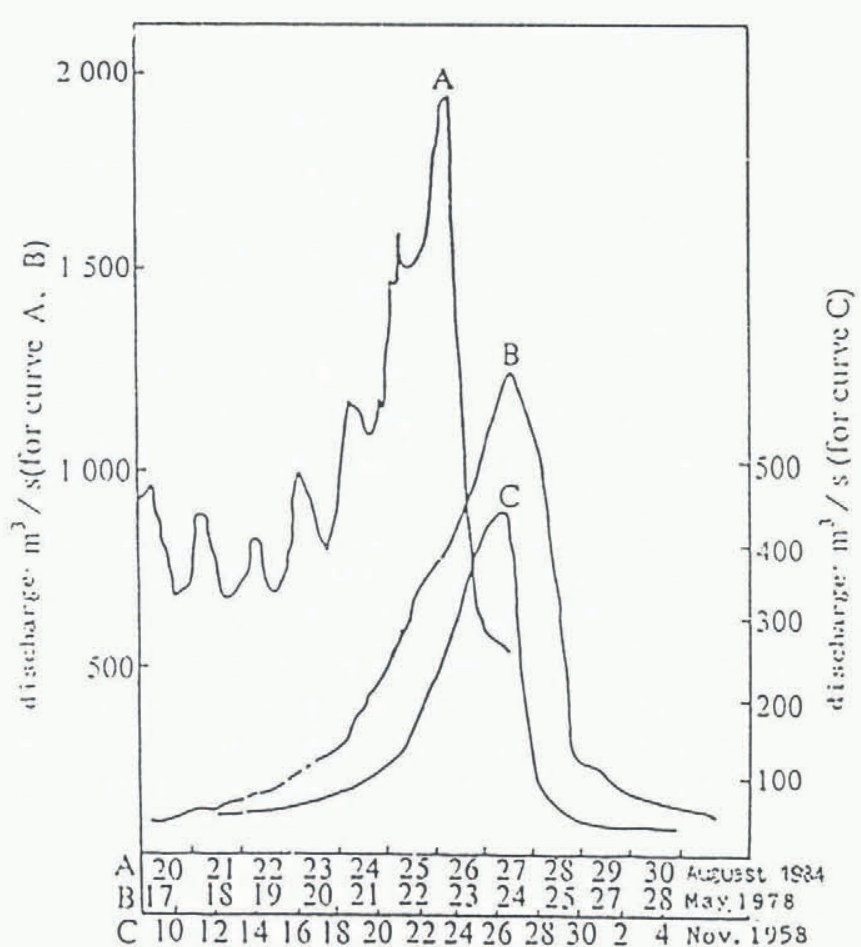

Fig. 2. Hydrographs of jökulhlaups at the gauge Xiehela stream in Kunmalike River.

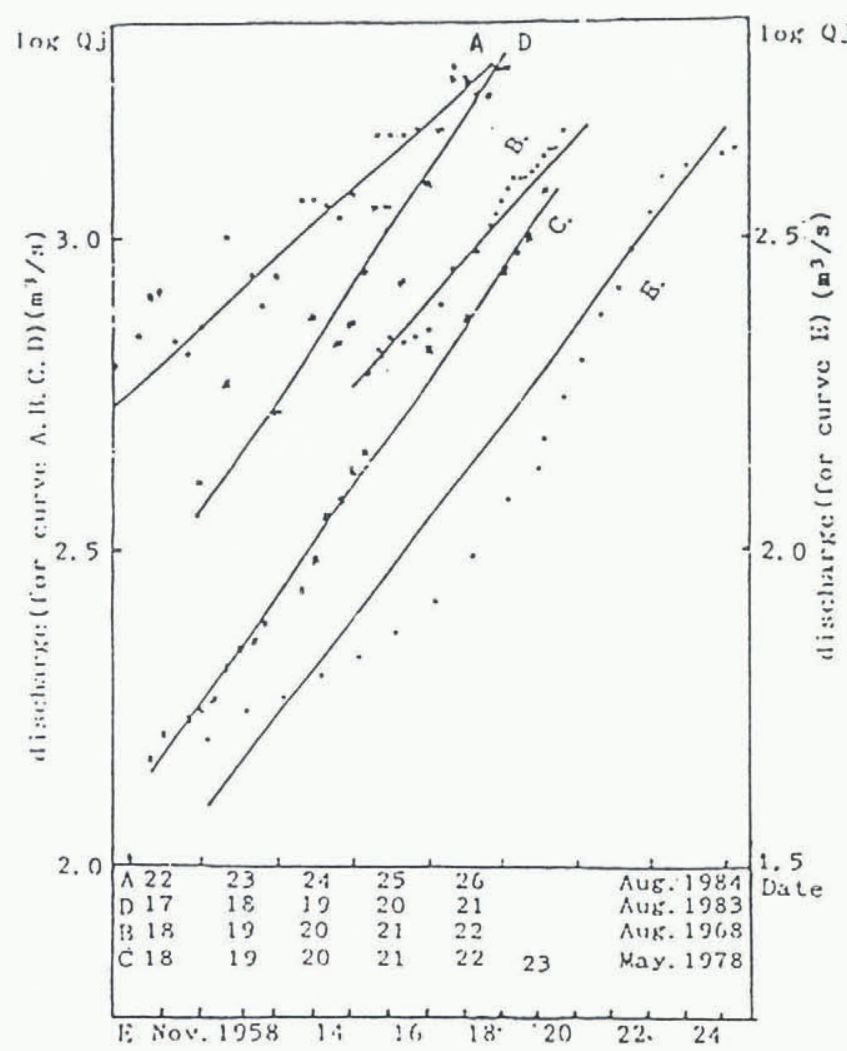

Fig. 3. Comparison of measured and simulated hydrographs by an exponential relationship $\left(Q_{0}\right.$ in $\left.\mathrm{m}^{3} \mathrm{~s}^{-1}\right)$ : A. 22 August 1984, $Q_{\mathrm{o}}=543, b: 0.0103$.

B. 18 August 1968, $Q_{\mathrm{o}}=590, b: 0.012$

C. 18 May $1978, Q_{0}=139, b: 0.0166$

D. 17 August 1983, $Q_{\mathrm{o}}=366, b: 0.0178$

E. 9 November $1958, Q_{0}=38.9$ b: 0.168 .

Each division on the abcissa is 1 day for events $A, B, C$ and $D$, and 2 days for event $E$. Symbols ( $x$ and .) show measured hydrographs; lines (-) show simulated hydrographs. the maximum discharge of seasonal melt floods at the stream gauge.

\section{THE RELEASE MECHANISM AND FORECAST- ING OF JÖKULHLAUPS}

The shapes of the hydrographs of the jökulhlaups indicate that the water drains out of the lake through gradually enlarging subglacial tunnels. This was verified by Golubev (1977) after a jökulhlaup in 1971. The hydrographs are quite different from those of jökulhlaups in the Yarkant River on the northern side of the Karakoram mountains where a lake sometimes drains after a mechanical failure of a glacier dam.

Prediction of the timing of the jökulhlaups is difficult. The lake sometimes drains after its level has reached 0.9 of the height of the ice dam. However, jökulhlaups have been triggered at lower lake levels. Further, conditions of the glacier dam and the lake are different from year to year and they are difficult to survey.

Prediction of the hydrographs of the jökulhlaups is also difficult using theoretical models such as those derived from Nye (1976), Mathews (1973), Spring and Hutter (1981), and Clarke (1982). Such predictions would require data on the lake volume-distribution with elevation, and on temperature of the lake. These data are not readily available. Therefore, a forecasting method is advocated based on statistics and characteristics of their hydrographs.

If the mean diurnal discharge of the river increases at a rate of $200 \mathrm{~m} \mathrm{~s}^{-1}$ per 24 hours over two or three days, a jökulhlaup is probably in progress. Further, as the peak discharge only exceeds $1280 \mathrm{~m}^{3} \mathrm{~s}^{-1}$ in jökulhlaups in summer, a jökulhlaup can be expected if the discharge

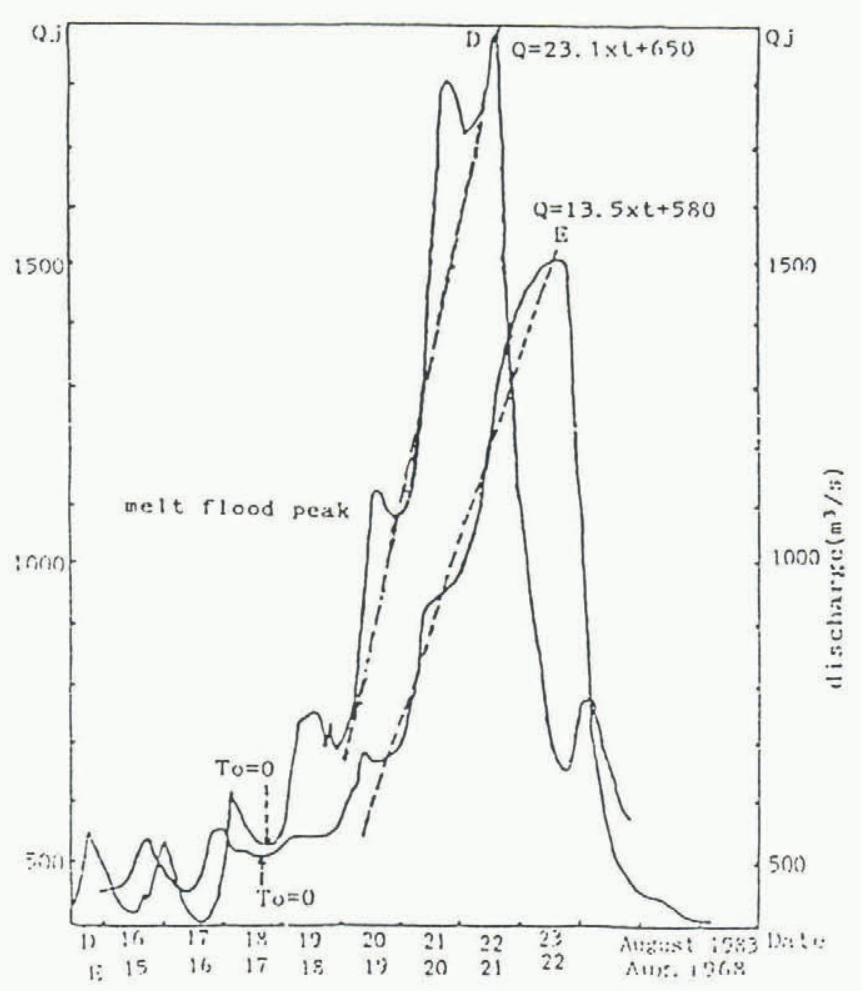

Fig. 4. Comparison of measured and simulated hydrographs by a linear relationship. 
exceeds that value. The prediction is done by extrapolating the jökulhlaup component, $Q_{\mathrm{j}}$. This component is derived from the measured hydrograph, $Q$, by subtracting the base flow, $Q_{0}$, and the diurnal meltwater component, $Q_{\mathrm{m}}$, from the recorded discharge.

The rise of the jökulhlaup component of a flood can be simulated by the exponential relationship

$$
Q_{\mathrm{j}}=Q_{\mathrm{o}} \exp (\mathrm{b} t)
$$

where $Q_{0}$ is a base value for the discharge at time $t=o$ and $\mathrm{b}$ is a constant. Both $Q_{\mathrm{o}}$ and $\mathrm{b}$ are obtained by fitting an exponential curve to the hydrograph of the jökulhlaup. Figure 3 shows the values obtained for $b$.

The peak discharge of the jökulhlaups cannot be predicted accurately becasue we cannot predict the timing of the peak. Table 1 , however, shows that the development of a jökulhlaup takes at least $3.5 \mathrm{~d}$ and usually $5 \mathrm{~d}$.

In most of the jökulhlaups $(90 \%)$ the discharge increases approximately linearly with time after the first two days. Figure 4 compares a linear relationship with the measured hydrographs. The mean error of using the linear relationship is $10 \%$ of the measured discharge.

\section{REFERENGES}

Clarke, G. K.C. 1982. Glacier outburst floods from "Hazard Lake", Yukon Territory, and the problem of flood magnitude prediction. F. Glaciol., 28(98), 3-21.

Golubev, D. 1977. The cause of the glacier flood and glacier debris flows. In Hydrology of glaciers. Scientific Publisher of USSR, 213-238.

Mathews, W.H. 1973. Record of two jökulhlaups. International Association of Scientific Hydrology Publication 95 (Symposium at Cambridge 1969 - Hydrology of Glaciers), 99-110.

Nye, J.F. 1976. Water flow in glaciers; jökulhlaups, tunnels and veins. F. Glaciol., 17(76), 181-207.

Spring, U. and K. Hutter. 1981. Numerical studies of jökulhlaups. Cold Reg. Sci. Technol., 4(3), 227-244.

Zhang Xiongshong. 1989. The cause of the flash floods in the Yarkant River. Study on the glacier lake outburst floods of the rarkant River, Karakoram mts. Scientific Publisher of China, 46-57.

The accuracy of references in the text and in this list is the responsibility of the author/s, to whom queries should be addressed. 